\title{
PENTINGNYA SELEKSI CALON MISIONARIS DAN IMPLEMENTASINYA DALAM PEKERJAAN MISI DI INDONESIA
}

\author{
${ }^{1}$ Sari Saptorini, ${ }^{2}$ Karnawati \\ Sekolah Tinggi Teologi Baptis Indonesia \\ JL. Simongan, No. 1, Bojongsalaman, Semarang Barat, Jawa Tengah 50141 \\ Email:sarisaptorini@stbi.ac.id',karnawati@stbi.ac.id²
}

\begin{abstract}
ABSTRAK: Pengutusan misionaris diperlukan untuk menjangkau suku terabaikan di Indonesia. Oleh karena itu diperlukan misionaris yang siap menghadapi segala situasi dan kondisi. Penelitian ini bertujuan menggali pentingnya seleksi calon misionaris. Metode yang digunakan adalah studi kepustakaan. Penelitian ini menemukan bahwa seleksi calon misionaris penting untuk dilakukan bagi pekerjaan misi di Indonesia. Tahapan dalam proses seleksi, yaitu: pendafaran atau perekrutan, wawancara, penilaian atau tes, keputusan hasil seleksi. Proses seleksi memeriksa calon secara menyeluruh yang meliputi hal latar belakang, motivasi, kompetensi, karakter dan kepribadian. Proses ini dapat menolong gereja dan lembaga misi untuk mengutus misionaris yang sesuai dengan kebutuhan yang ada di ladang misi.
\end{abstract}

Kata Kunci: seleksi; misionaris; ladang misi

\section{THE IMPORTANCE OF THE MISSIONARY CANDIDATE SELECTION AND ITS IMPLEMENTATION IN THE MISSION WORK IN INDONESIA}

\begin{abstract}
Missionaries are needed to reach the unreached people groups in Indonesia. Therefore, we need missionaries who are prepared to face all situations and conditions. This study aims to examine the importance of the selection of prospective missionaries. The method used is a literature study. The study results show that the selection of missionary candidates is important for mission work in Indonesia. The selection process stages are registration or recruitment, interview, observation or test, and selection result. The selection process observes the candidates as a whole, which includes background, motivation, competence, character and personality. This process can help churches and mission agencies send a missionary that suits the mission field's needs.
\end{abstract}

Keywords: selection; missionaries; mission field 


\section{PENDAHULUAN}

Pengutusan misionaris dibutuhkan agar kabar baik dapat didengar oleh semua orang dari segala bangsa. Dalam Roma 10:13-15, Rasul Paulus mencatat bahwa kabar baik keselamatan di dalam Kristus perlu diberitakan kepada orang-orang yang belum percaya supaya mereka beroleh kesempatan untuk mendengar, kemudian percaya dan diselamatkan. Melalui pengutusan misionaris, Injil dapat didengar oleh segala bangsa, mulai dari Yerusalem sampai ke ujung bumi. Akan tetapi realitas yang terjadi hingga sekarang ini, masih banyak suku-suku bangsa yang belum mendengar Injil, termasuk yang ada di Indonesia, oleh karena Injil belum "melompat" melewati batas-batas geografis, rasial, bahasa dan budaya. Hal itu dikarenakan sejak pengutusan misionaris yang pertama oleh gereja hingga hari ini, selalu ada tantangan dan kesulitan yang menghadang pekerjaan misi (Gallego \& Woodberry, 2010).

Kemampuan para misionaris dalam bertahan dan melewati setiap kendala di ladang misi turut menentukan keberhasilannya dalam menanam benih Injil dan menuai petobatpetobat baru (Coustneau, n.d.). Salah satu penelitian yang pernah dilakukan berkaitan dengan topik tersebut hanya meninjau dari sudut psikologis dan spiritual. Dengan demikian penelitian ini bertujuan untuk menggali pentingnya seleksi calon misionaris serta menawarkan implementasinya bagi pekerjaan misi secara khusus di Indonesia.

\section{METODE}

Penelitian ini menggunakan metode kepustakaan, yaitu dengan melakukan penelusuran pustaka sekaligus memanfaatkan sumber perpustakaan untuk memperoleh data penelitian (Zeid, 2008). Data diperoleh dengan mengumpulkan referensi dari sumber-sumber yang relevan yaitu dari Alkitab, buku-buku yang berhubungan dengan pekerjaan misi diantaranya "The Selection Process and the
Issue of Attrition"; How to Choose the Right Missionary"; dan Current Issues in Screening and Selection", serta sumber web yang kredibel mengenai data kependudukan di Indonesia. Data yang terkumpul kemudian dideskripsikan dan dianalisis, yang akhirnya menghasilkan sebuah kesimpulan yang berguna untuk memberi rekomendasi. Dengan demikian gereja lokal maupun lembaga misi di Indonesia dapat melakukan seleksi misionaris untuk memperoleh misionaris yang sesuai dengan kebutuhan yang ada di ladang misi.

\section{HASIL DAN PEMBAHASAN}

\section{Panggilan Misionaris}

Misionaris adalah seorang Kristen yang melintasi batasan-batasan budaya untuk memperluas pembangunan gereja Kristus dan kerajaan Allah (Hale, 1995, p. 8). Misionaris adalah orang yang menaati panggilan Allah untuk bekerja di ladang misi. Ladang misi adalah tempat orang-orang yang belum percaya kepada Kristus, khususnya area-area di mana hanya sedikit atau bahkan tidak ada orang-orang Kristen (Hale, 1995, p. 9).

Seseorang menjadi misionaris bukan karena pilihan melainkan diawali dengan panggilan dari Tuhan dan kemudian menaatinya (Hale, 1995, p. 16). Seseorang bisa saja menerima panggilan sebagai misionaris namun tidak menaatinya. Ada beberapa alasan mengapa seseorang menolak panggilan tersebut, misalnya: rasa takut, keengganan untuk meninggalkan zona nyaman, dan tidak peduli akan orang-orang yang belum diselamatkan. Alkitab mencatat kisah Yunus, seorang nabi yang dipanggil Allah untuk memberitakan pertobatan kepada bangsa Niniwe. Namun Ia menolak dan memilih untuk pergi ke Tarsis. Pada akhirnya ia bersedia pergi ke Niniwe setelah Allah menegurnya lewat peristiwa angin ribut pada saat pelariannya. Hasil dari ketaatan Yunus adalah pertobatan orang-orang Niniwe. Allah berkenan untuk menyelamatkan 
manusia. Allah meminta ketaatan orang-orang yang dipanggilnya untuk melintasi batasan geografis, budaya dan bahasa untuk menyampaikan berita keselamatannya.

Panggilan umum datang dari Alkitab, sedangkan panggilan khusus datang terutama dari Roh Kudus. Roh Kudus menggunakan Alkitab untuk menegaskan panggilan khususNya kepada orang percaya untuk menjadi misionaris (Hale, 1995, p. 17). Hal itu berarti bahwa semua orang percaya dipanggil untuk memberitakan Injil. Meskipun demikian, tidak semua orang percaya dipanggil secara khusus untuk pergi ke suatu suku bangsa tertentu dan melakukan penginjilan di sana. Hal tersebut juga dinyatakan oleh M. David Sills dalam bukunya, The Missionary Call, bahwa Amanat Agung Kristus ditujukan bagi gereja dalam menjangkau dan mengajar bangsa-bangsa. Setiap orang percaya harus berdoa bagi bangsa-bangsa dan mendukung pelayanan misi, tetapi tidak semua orang percaya dipanggil untuk meninggalkan kampung halamannya dan pergi keluar negeri. Beberapa orang menolong dan mendukung, sementara yang lainnya pergi dan memberitakan (Sills, 2008, p. 6).

Orang-orang yang dipanggil Allah untuk bekerja di ladang misi adalah mereka yang memiliki kesadaran akan kebutuhan bangsa-bangsa dan kesadaran akan perintah Kristus, perhatian akan orang-orang tersesat, komitmen kepada Allah, karunia Roh Kudus dan pengutusan (Sills, 2008, p. 6). Selain itu panggilan tersebut harus dikonfirmasi oleh orang-orang lain dalam gereja lokal (Hale, 1995, p. 19). Mereka akan dapat mengenali karunia dan panggilan dalam hidup seorang Kristen untuk melayani sebagai misionaris (Sills, 2008, p. 12). Dengan demikian, penting bagi seseorang yang merasa bahwa Tuhan memanggilnya untuk menjadi misionaris untuk memastikan panggilannya sehingga akan semakin jelas kapan dan di mana ia akan diutus.

\section{Kebutuhan akan Misionaris di Ladang Misi}

Misionaris masih diperlukan mengingat ada kebutuhan yang sangat besar yakni sepertiga bumi, lebih dari dua milyar penduduk belum pernah mendengar Injil. Dari jumlah tersebut, lebih dari 50.000 orang setiap hari meninggal dunia, terpisah dari Allah selamanya (Sills, 2008, p. 12). Orang-orang tersebut sebagian besar berada pada kelompok suku-suku terabaikan. Berdasarkan data dari Joshua Project, diketahui jumlah suku di dunia adalah 17.014 dan dari jumlah tersebut terdapat sebanyak 7.079 atau $41,6 \%$ suku terabaikan dengan populasi 3,15 milyar yang membutuhkan misionaris datang untuk memberitakan Injil kepada mereka (Sills, 2008, p. 12). Suku terabaikan adalah suku yang tidak memiliki akses kepada Injil. Mereka "tersembunyi" bukan dalam pengertian tidak terlihat, namun dalam pengertian tidak ada jalan, oleh karena kondisi yang ada, di mana mereka dapat mendengar Injil dalam bahasa mereka sendiri dengan cara yang masuk akal bagi mereka (Moreau et al., 2015, p. 23). Adapun definisi strategis mengenai kelompok suku terabaikan (an unreached people group) dihasilkan dalam pertemuan para pemimpin misi di Chicago pada bulan Maret 1982 yang disponsori oleh Lausanne Strategy Working Group, yakni: "An unreached people group is a people group within which there is no indigenous community of believing Christians able to evangelize this people group" (Winter, 2002, p. 19).

Dengan demikian, kelompok suku terabaikan merupakan ladang misi yang perlu untuk digarap oleh misionaris supaya orangorang yang belum percaya bisa mendengar Injil yang jelas dalam bahasa mereka sendiri dan bertumbuh menjadi komunitas Kristen pribumi yang dapat menginjili suku mereka sendiri. 


\section{Bagaimana Misionaris Diutus ke Ladang Misi}

Ada beberapa misionaris yang mengatakan bahwa mereka diutus hanya oleh Roh Kudus dan oleh karena itu tidak berada di bawah otoritas badan Kristen apa pun. Memang benar bahwa Roh Kudus adalah Sang Pengutus utama, akan tetapi Ia mengutus misionaris sebagai bagian dari tubuh Kristus, yaitu gereja. Di dalam Alkitab, kisah Paulus dan Barnabas menjadi contoh nyata berkenaan dengan pengutusan misionaris oleh Roh Kudus melalui gereja lokal. Oleh karena kebanyakan gereja lokal tidak dapat dengan mudah menjaga dan mengawasi misionaris di lapangan, mereka bergantung pada badan misi denominasi mereka atau meminta lembaga misi untuk menolong mereka melakukan pekerjaan tersebut. Akan tetapi hal itu tidak berarti bahwa gereja lokal boleh melepaskan tanggung jawabnya sebagai pengutus utama para misionaris (Hale, 1995, p. 49). Gereja lokal harus menjadi gereja yang mengutus. Zach Bradley, dalam bukunya "The Sending Church Defined," mendefinisikan gereja yang mengutus sebagai:

... a local community of Christ's followers who have made a covenant together to be prayerful, deliberate, and proactive in developing, commissioning and sending their own members both locally and globally, often in partnership with other churches and mission agencies, and continuing to encourage, support and advocate for them while making disciples cross-culturally (Bradley, 2015, p. 8).

Allah memberikan tugas pengutusan kepada gereja-Nya. Gereja lokal yang tidak terlibat dalam pengutusan sedang menunjukkan keengganannya terlibat dalam misi Allah dan ketidaktaatan kepada panggilan Allah. Gereja dapat terlibat dalam pengutusan misionaris dengan berbagai macam cara, antara lain: mengutus dan memfasilitasi anggota gereja yang terpanggil menjadi misionaris baik di dalam maupun di luar negeri, bermitra dengan misionaris, menyokong lembaga misi dalam doa, daya dan dana, serta mengadopsi pelayanan suku terabai.

\section{Pentingnya Seleksi Calon Misionaris}

Menjadi misionaris bukanlah pekerjaan yang mudah bahkan bagi mereka yang terpanggil sekalipun. Pengunduran diri misionaris dari ladang misi bukanlah hal yang baru ditemukan dalam pekerjaan misi di negaranegara seluruh dunia (Taylor, 1997, p. 11). Pengunduran tersebut dalam bahasa Inggris menggunakan istilah attrition yang berarti misionaris meninggalkan ladang misi sebelum waktunya. Paul McKaughan menyatakan bahwa problem ini muncul karena pengelolaan yang keliru, harapan-harapan yang tidak realistis, penyalahgunaan sistemis, kegagalan pribadi atau alasan-alasan pribadi lainnya (McKaughan, 1997, p. 18). Sedangkan Hakim menyatakan bahwa salah satu penyebab mundurnya misionaris dari ladang misi adalah tantangan dari keluarga, sehingga diperlukan pengertian dan dukungan dari pihak keluarga misionaris (Hakim, 2019). Meskipun ada berbagai faktor yang menjadi penyebab seorang misionaris meninggalkan ladang misi sebelum waktu yang ditetapkan baik oleh gereja dan lembaga misi pengutus maupun komitmen pribadinya, proses seleksi merupakan tahap pertama yang penting dan patut untuk dilakukan dengan sungguh-sungguh demi meminimalkan terjadinya attrition tersebut.

Ada dua macam seleksi, yakni pertama, seleksi yang dilakukan oleh misionaris mencakup seleksi lembaga misi pengutus dan seleksi ladang misi. R. Zarwulugbo Liberty, penulis Growing Missionaries Biblically A Fresh Look at Missions in African Context, mengatakan bahwa seorang misionaris harus mendoakan dengan sungguh-sungguh lembaga misi yang akan menjadi pengutusnya. Hal itu penting 
bagi keberhasilan misionaris dan pelayanannya. Lembaga misi pengutus harus memegang doktrin ortodoks dan praktik-praktik etis, serta memiliki reputasi yang baik. Selain itu ia juga memiliki penekanan yang kuat akan studi dan komunikasi antarbudaya. Lembaga pengutus yang baik memberikan program pelatihan yang efektif dalam melengkapi misionaris dan mempersiapkannya bagi ladang misi yang ditentukan. Demikian pula seorang misionaris harus mendoakan dengan tekun mengenai lokasi penempatannya. Kegagalan banyak misionaris terjadi dikarenakan mereka pergi ke area yang tidak ditugaskan oleh Kristus kepada mereka (Liberty, 2012, p. 160). Hal tersebut tentunya bukan hanya berlaku dalam konteks Afrika, melainkan bagi misionaris di seluruh dunia.

Kedua, seleksi yang dilakukan oleh lembaga misi terhadap calon misionaris. Seleksi inilah yang selanjutnya akan dibahas secara khusus dalam tulisan ini. Seleksi lembaga misi terhadap calon misionaris merupakan hal yang penting agar pihak lembaga misi tidak sekadar menerima mereka yang mendaftar dan mengaku mendapatkan panggilan untuk menjadi misionaris. Hal itu diperlukan karena misionaris adalah utusan yang akan pergi ke ladang misi untuk mengomunikasikan pesan Injil kepada orangorang yang belum mengenal Kristus. Pengutusan misionaris tanpa seleksi yang dilakukan secara sungguh-sungguh menimbulkan risiko kegagalan pekerjaan misi dan penghamburan sumber daya secara cumacuma.

\section{Pihak Penyeleksi Calon}

Pihak yang berwenang untuk melakukan seleksi terhadap calon misionaris tentunya adalah pihak pengutus, baik itu gereja lokal maupun lembaga misi. Ada dua kecenderungan penyeleksian yang pernah terjadi, yakni kecenderungan di kalangan lembaga misi dan kecenderungan di kalangan gereja. Pada lembaga-lembaga misi ada kecenderungan mengenai penggunaan alat dan teknik dari ilmu sosial modern, seperti alat tes kepribadian dan psikologi. Penggunaan alat dan teknik tersebut semakin berkembang seiring dengan meningkatnya calon misionaris yang hanya sedikit atau bahkan tidak berafiliasi dengan gereja lokal.

Sementara itu di kalangan gereja lokal berkembang kecenderungan melakukan seleksi calon misionarisnya tanpa melibatkan lembaga misi. Bukan hanya dalam hal seleksi, melainkan juga dalam persiapan dan pengutusan. Hal itu mengakibatkan polaritas antara gereja-gereja lokal dan lembaga-lembaga misi dalam penyeleksian dan pengutusan pekerja misi. Seharusnya gereja lokal dan lembaga misi menjalin kemitraan di sepanjang proses tersebut (Platt, 1997, pp. 196-197). Kemitraan yang dilakukan oleh gereja lokal dan lembaga misi dalam penyeleksian calon misionaris mestinya dapat diwujudkan dengan pembagian tugas. Gereja lokal dapat berfungsi sebagai penyeleksi pertama bagi anggota gereja yang merasa terpanggil menjadi misionaris. Gereja lokal perlu memastikan kesungguhan akan panggilannya serta komitmennya untuk menanggapi panggilan tersebut. Pihak penyeleksi perlu mempertimbangkan komitmen awal calon karena komitmen yang kuat akan memampukan misionaris bertahan di ladang misi sekalipun di tengah tantangan dan penderitaan. Hal itu penting karena komitmen misionaris dan keinginannya meninggalkan pelayanan dipengaruhi oleh kepuasan kerja yang diperoleh di ladang misi (Hakim, 2019). Setelah memastikan panggilan dan komitmen calon, gereja lokal memberikan rujukan kepada lembaga misi yang akan menjadi penyeleksi tahap selanjutnya disertai dengan surat referensi. Lembaga misi inilah yang pada akhirnya akan memutuskan apakah calon misionaris tersebut diterima atau ditolak setelah menjalani proses dan prosedur seleksi yang diadakannya. 


\section{Proses Seleksi Calon}

Proses dan prosedur seleksi yang dilakukan bertujuan untuk memperoleh profil total calon misionaris yang akan diutus. Berikut ini disampaikan beberapa pandangan para ahli berkaitan dengan proses seleksi. Dalam penyeleksian calon misionaris, LeRoy N. Johnston menyarankan tiga pertanyaan yang perlu diajukan kepada calon tersebut, yakni: pertama, mengapa ia ingin pergi keluar negeri? Hal-hal yang berkaitan dengan pertanyaan pertama ini adalah keyakinan akan panggilan melayani sepenuh waktu, afirmasi tentang pemenuhan persyaratan alkitabiah dari para pemimpin rohani yang mengenalnya sebagai verifikasi atas panggilannya, dukungan ayat-ayat Alkitab dan pengalaman-pengalaman praktis kehidupan yang dimiliki oleh calon tersebut berkaitan dengan pelayanan misi.

Kedua, apakah ia dapat melaksanakan tanggung jawab yang diharapkan darinya ketika ia berada dalam posisi luar negeri? Berkaitan dengan hal ini, maka ia perlu memiliki pemahaman dasar tentang misi, keterampilan dan pendekatan-pendekatan dalam pekerjaan misi, kualitas kepribadian yang baik serta tinjauan mengenai akuntabilitas dalam pengalaman pelayanannya. Ketiga, bagaimana persiapan yang akan dilakukannya untuk menyelesaikan pelayanan yang mana Tuhan telah memanggilnya? Persiapan tersebut menyangkut rencana hidup, akuntabilitas, kesiapan serta sikap kesabarannya. Kebanyakan lembaga misi menginginkan calon misionaris yang memiliki energi, kehidupan, antusiasme, hasrat dan minat (Johnston, 1997, pp. 18-25).

David Wilson mengusulkan aspek kompetensi, karakter, budaya dan panggilan dalam mempertimbangkan calon misionaris yang akan diutus (Wilson, 2015, p. 35). Daryll Platt juga menyarankan empat aspek pertimbangan, yaitu: Pertama, kehidupan rohani yang meliputi pertobatan, keyakinan, panggilan dan pengutusan. Kedua, karakter Kristen yang mencakup reputasi baik, terpercaya, dan hati hamba. Ketiga, keterampilan pelayanan yakni dalam hal pengetahuan Alkitab, kemampuan komunikasi, kerja tim dan kepemimpinan hamba. Keempat, pola-pola hubungan dalam pelayanan penggabungan, pembentukan, keikutsertaan dan pertanggungjawaban (Platt, 1997, pp. 205-206).

Sementara itu, ada ahli-ahli lain yang menganggap penting untuk memasukkan pemeriksaan psikologis dalam proses seleksi. Hal itu dikarenakan faktor psikologis turut mempengaruhi efektivitas misionaris di ladang misi. Sebuah penelitian yang dilakukan terhadap kesehatan mental 393 orang misionaris membuktikan bahwa sebanyak 47,9\% misionaris wanita dan 42,1\% misionaris pria mengalami kegelisahan, sementara 32,5\% misionaris wanita dan 27,5\% misionaris pria mengalami depresi (Strand et al., 2015). Andreas Sudjono juga menyatakan bahwa mentalitas yang baik turut menentukan keberhasilan pelayanan misionaris (Sudjono, 2013). Kondisi psikologis calon misionaris penting diketahui sebelum ditugaskan ke ladang misi. Apabila dalam proses seleksi seorang calon didapati sedang dalam keadaan psikis yang tidak memenuhi syarat, disarankan pihak penyeleksi untuk menunda atau menolak penugasannya ke ladang misi.

Di antara para ahli tersebut ada Marjory Foyle yang mengusulkan tiga sarana untuk dipakai dalam proses seleksi, yaitu formulir yang memuat keterangan data diri calon, referensi baik dari gereja lokal maupun sekolah tinggi teologi dan wawancara pribadi yang mencakup hal-hal umum, pemeriksaan medis serta kesehatan mental-psikologis (Foyle, 1988, pp. 26-27). Dalam proses seleksi, ada area-area sensitif khusus yang perlu dibahas. Dalam hal ini pihak penyeleksi harus memahami terlebih dahulu latar belakang budaya calon supaya dapat menanyakan dan menyampaikan hal-hal tersebut dengan bijak. Adapun area-area tersebut antara lain: kehidupan seksual, kelajangan, problem pernikahan, pengalaman 
okultisme, keterlibatan sebelumnya dengan obat-obatan terlarang, dan peristiwa patah hati atau kehilangan seseorang yang dikasihi yang belum lama terjadi (Foyle, 1988, pp. 30-31).

Selain itu, kepribadian calon misionaris juga harus dipertimbangkan dalam proses seleksi. Meskipun Tuhan menghargai semua tipe kepribadian, ada beberapa faktor yang perlu mendasari tiap kepribadian, yakni berwawasan, mampu beradaptasi, mengetahui kekuatan dan kelemahan pribadi dan bersikap rendah hati (Foyle, 1988, pp. 32-33). Penyimpangan kepribadian calon juga perlu diwaspadai. Proses dan prosedur seleksi yang menyeluruh tentunya akan menghasilkan pula misionaris yang berkualitas.

Selain Foyle, ada Esther Schubert, dalam artikelnya "Current Issues in Screening and Selection," yang memaparkan perlunya mewaspadai para calon misionaris yang berasal dari latar belakang sulit dan rusak. Beberapa sumber umum bagi luka masa lalu di antara calon misionaris adalah disfungsi keluarga, melibatkan: (a) orang dewasa yang merupakan korban kekerasan atau pengabaian pada anak; (b) anak dari pecandu alkohol; (c) orang dewasa yang bertahan dari kekerasan seksual; (d) duka cita, rasa bersalah, kemarahan atau ketakutan yang belum terselesaikan; (e) isu adopsi dan perceraian; (f) problem identitas seksual; (g) perilaku seksual sebelumnya, termasuk jika pernah melakukan aborsi; dan (h) keterlibatan dengan setan (Schubert, 1992, p. 75). Luka masa lalu tersebut perlu untuk diketahui melalui tes yang dilakukan pada proses seleksi untuk memperoleh informasi apakah calon berpotensi mengalami penyimpangan kepribadian. Dengan mengetahui hal itu sejak dini pada diri calon, diharapkan dapat meminimalkan kemungkinan kegagalan di ladang misi.

Bertil Ekström mengusulkan beberapa kriteria dasar bagi seleksi calon pekerja ladang misi di Dunia Dua Pertiga, yaitu: (1) pengalaman lahir kembali; (2) motivasi yang benar; (3) panggilan sejati dari Allah; (4) karakter Kristen dan kedewasaan rohani; (5) hubungan yang baik dengan orang-orang lain; (6) kemampuan untuk mengatasi stres; (7) pengetahuan Alkitab yang bagus; (8) pelatihan misiologis; (9) keterampilan profesional; dan (10) pengakuan sebagai manusia yang memiliki kekuatan, kebutuhan dan kelemahan (Ekström, 1997, pp. 183-193). Sedangkan untuk proses seleksi, Ekström merekomendasikan beberapa aspek fundamental yang harus dilaksanakan dengan serius, yaitu pertama, mengajarkan tentang pekerjaan misionaris. Di sinilah peran gereja lokal untuk memberikan pengajaran Alkitab mengenai panggilan Allah pada tugas khusus sebagai misionaris. Dengan demikian, calon akan melibatkan komunitas mereka dalam proses persiapan menuju ladang misi. Kedua, berpikir melampaui proses seleksi. Kebutuhan akan misionaris mengalami perubahan baik dalam hal adaptasi budaya maupun kemampuan profesional. Proses seleksi memerlukan revisi untuk merefleksikan kecenderungan-kecenderungan masa kini dalam misi. Kecenderungan misionaris "pembuat tenda" terus berkembang sehingga diperlukan untuk menyesuaikan mereka ke dalam proses seleksi dan juga program pelatihan. Ketiga, menaikkan standar seleksi. Tujuan menaikkan standar seleksi bukanlah untuk menghalangi orang pergi ke ladang misi, melainkan untuk mengusahakan misionaris dengan kualitas yang lebih baik.

Keempat, memberitahukan calon keseluruhan ceritanya. Calon harus mengetahui terlebih dahulu realitas di ladang misi. Hal ini dapat dilakukan dengan merekomendasikan kepada calon pengalaman misi jangka pendek di ladang misi tertentu. Kelima, menggunakan beberapa metode untuk mengenal calon. Wawancara, tes psikologis, tes medis adalah sarana yang baik untuk dapat mengenali calon apakah sesuai atau tidak untuk diutus ke ladang misi. Keenam, mengembangkan proses 
seleksi dalam kerja sama dengan pihak-pihak lain. Setiap lembaga misi memiliki sistem yang berbeda, akan tetapi jika dapat ditemukan standar umum bagi seleksi, hal itu akan menguatkan pergerakan nasional secara keseluruhan. Para calon juga akan mengetahui bahwa di semua lembaga, mereka akan diperhadapkan dengan persyaratan- persyaratan yang sama. Kerja sama dalam proses seleksi diperlukan pula apabila misionaris yang kelak diutus akan bermitra dengan gerejagereja di ladang misi. Ketujuh, melatih para pemimpin gereja untuk melakukan seleksi. Keikutsertaan para pemimpin gereja dalam proses seleksi calon misionaris masih sangat terbatas. Maka diperlukan pelatihan bagi mereka yang dapat diberikan oleh lembagalembaga misi. Dengan demikian, gereja bukan hanya memiliki individu penyeleksi, melainkan panitia seleksi untuk menilai anggotanya yang merasakan panggilan Tuhan untuk menjadi misionaris. Kedelapan, bergantung kepada Roh Kudus. Tuhanlah yang memberikan pertumbuhan dan kemajuan dalam pekerjaan misi. Cara manusia untuk mengevaluasi orang-orang maupun situasi-situasi tidak selalu benar. Oleh sebab itu, hikmat dan kemurahan Tuhan serta pimpinan Roh Kudus sangat diperlukan dalam proses penyaringan dan seleksi calon misionaris (Ekström, 1997, pp. 190-192).

Selain dari pandangan beberapa ahli di atas, berikut ini juga akan dipaparkan mengenai aspek-aspek dalam proses seleksi calon misionaris yang dilakukan oleh lembaga-lembaga misi di Afrika Selatan dan lembagalembaga misi anggota Evangelical Foreign Mission Association (EFMA). Lembagalembaga misi di Afrika menyeleksi calon-calon misionaris dengan memperhatikan segi-segi umum berikut ini, yaitu: (1) mensahihkan panggilan dan visi misionaris; (2) persyaratan pendidikan dan pelatihan; (3) dukungan gereja lokal; (4) penilaian doktrinal; (5) penilaian psikologis; (6) penilaian medis; dan (7) referensi karakter. Pada dasarnya proses seleksi dilakukan untuk mengetahui seluruh bidang kehidupan calon tersebut sehingga orangorang yang diutus ke organisasi dan ladang misi adalah orang-orang yang tepat pada waktu yang tepat (Hay, 2007, pp. 75-77).

Sedangkan EFMA mengajukan serangkaian pertanyaan dalam proses seleksinya serta mempertimbangkan faktor-faktor yang meliputi: faktor status latar belakang, faktor pelatihan, faktor sumber daya pribadi dan faktor validasi. Serangkaian pertanyaan tersebut diwujudkan dalam sejumlah tahapan wawancara yang dilakukan oleh beberapa pihak, yaitu (Hay, 2007, p. 37):

1. Tahap wawancara dengan staf lembaga misi untuk pra-pendaftaran.

2. Tahap kedua wawancara dengan anggota badan misi setelah penerimaan.

3. Tahap ketiga wawancara secara informal misionaris lain.

4. Tahap keempat wawancara dengan psikiater dilakukan apabila ditemukan problem-problem khusus

5. Tahap kelima wawancara dengan psikolog untuk interpretasi dan evaluasi tes

6. Tahap keenam wawancara dengan yang lain seperti dokter, pendeta, panitia penyaringan apabila diperlukan

Adapun turunan dari empat faktor seleksi yang dipertimbangkan dalam penerimaan tersebut adalah sebagai berikut (Hay, 2007, p. 41):

1. Faktor status latar belakang, meliputi:

a. Kinerja dalam pekerjaan gereja

b. Status pernikahan (cerai/menikah kembali)

c. Keberhasilan pekerjaan sebelumnya

d. Studi mengenai peristiwa dan proses sejarah kehidupan

e. Asal usul keluarga (kesehatan fisik)

f. Status pernikahan (menikah/tidak 
menikah)

g. Ukuran keluarga (anak-anak?)

h. Lama usia pernikahan

2. Faktor pelatihan, meliputi:

a. Pengetahuan Alkitab

b. Tingkat pendidikan umum

c. Pelatihan teologi

e. Pelatihan misi

f. Bahasa/linguistik

g. Pelatihan antropologi

h. Pelatihan psikologi

3. Sumber daya pribadi, meliputi:

a. Kedalaman komitmen Kristen

b. Stabilitas emosional keseluruhan

c. Motivasi memilih misi luar negeri

d. Fleksibilitas/kemampuan beradaptasi

e. Kecerdasan/kemampuan intelektual

f. Kreativitas

g. Ketrampilan administratif

h. Kemampuan untuk melakukan pekerjaan pengutusan

i. Ketrampilan konstruksi

4. Faktor validasi, meliputi:

a. Kemampuan untuk berelasi dengan orang-orang dari budaya yang berbeda

b. Surat-surat referensi

c. Kecocokan kebutuhan-kebutuhan unik dengan karunia-karunia yang dimiliki oleh calon

d. Kemampuan untuk beradaptasi dengan lingkungan

e. Reaksi di bawah tekanan stres

f. Transkrip sekolah

g. Pemeriksaan yang memenuhi syarat

Dari sekian banyaknya faktor seleksi di atas, ada sebelas faktor yang dianggap paling penting dalam pertimbangan atas keputusan diterimanya seorang calon misionaris. Faktorfaktor tersebut adalah: kedalaman komitmen Kristen, pengetahuan Alkitab, kinerja dalam pelayanan gerejawi, stabilitas emosional keseluruhan, kemampuan untuk berhubungan dengan orang-orang dari budaya yang berbeda, fleksibilitas/kemampuan beradaptasi, motivasi memilih misi luar negeri, tingkat pendidikan umum, status pernikahan (cerai/menikah kembali), dan surat-surat referensi (Hay, 2007, p. 42).

Pada umumnya, proses seleksi tersebut diberlakukan bagi calon misionaris yang akan diutus ke luar negeri. Pengutusan misionaris ke berbagai wilayah di Indonesia, secara geografis tidak sejauh pengutusan ke luar negeri. Meski demikian ada faktor-faktor yang patut menjadi pertimbangan dalam proses seleksi calon misionaris di Indonesia. Hal itu dikarenakan Indonesia memiliki aneka ragam suku bangsa, budaya dan bahasa yang menuntut adanya pemenuhan syarat bagi calon misionaris. Faktor-faktor tersebut meliputi faktor panggilan, komitmen dan visi, faktor pengetahuan Alkitab dan pelatihan misi lintas budaya, dan faktor keluarga yang mendukung pelayanan misi lintas budaya.

Dalam proses seleksi, tentu ada keputusan yang diambil, yakni menerima atau menolak calon. Keputusan tersebut perlu diberitahukan secara jelas, khususnya kepada calon yang ditolak perlu disertai dengan alasan-alasan penolakan tersebut. Calon misionaris dinyatakan diterima setelah ia lolos dalam setiap tahap seleksi. Sedangkan penolakan dapat terjadi pada setiap tahap dalam prosedur seleksi. Dalam beberapa kasus, pendaftar mengundurkan diri. Dalam kasus lainnya penolakan terhadap calon terjadi karena dianggap tidak memenuhi persyaratan yang telah ditentukan maupun tidak lolos wawancara atau berbagai penilaian lainnya. Beberapa lembaga misi menemui serta memberikan penjelasan mengenai alasanalasan penolakan kepada calon. Apabila penolakan dikarenakan kesulitan emosional maupun personal, biasanya mereka akan membuat rujukan kepada psikiater atau 
psikolog selama diperlukan (Hay, 2007, pp. 4243).

\section{Implementasi Pentingnya Seleksi Calon Misionaris bagi Pekerjaan Misi di Indonesia}

Dalam bagian ini akan diuraikan mengenai ladang misi di Indonesia serta proses dan prosedur seleksi calon misionaris.

\section{Ladang Misi di Indonesia}

Indonesia merupakan negara kepulauan yang terdiri dari 17.506 pulau dan memiliki lebih dari tiga ratus Bahasa (Taylor, 2003, p. 1) dengan populasi sebesar 237.641.326 jiwa berdasarkan sensus penduduk yang terakhir dilakukan oleh Badan Pusat Statistik pada tahun 2010 (Data, n.d.). Sedangkan menurut proyeksi Badan Perencanaan Pembangunan Nasional (Bappenas) 2013, jumlah penduduk Indonesia pada tahun 2018 mencapai 265 juta jiwa. Jumlah tersebut terdiri dari 133,17 juta jiwa laki-laki dan 131,88 juta jiwa perempuan (Databoks, 2018).

Adapun jumlah suku di Indonesia berdasarkan analisis yang dilakukan oleh Badan Pusat Statistik (BPS) bekerja sama dengan Institute of Southeast Asian Studies (ISEAS) pada tahun 2013 dihasilkan 633 kelompok suku besar dari kode suku yang tersedia dalam Sensus Penduduk tahun 2010 di mana ada 1.331 kategori suku yang di dalamnya termasuk nama suku, nama lain/ alias suatu suku, nama sub suku, bahkan nama sub dari sub suku. Pengelompokan suku dilakukan berdasar literatur seperti buku ensiklopedi suku maupun dari pengetahuan para jejaring yang tersebar di seluruh Nusantara (Data, 2015). Ratusan suku bangsa tersebut tersebar di sepanjang garis Khatulistiwa, yakni dari Sabang sampai Merauke dan di sepanjang garis bujur Utara ke Selatan, yaitu dari Pulau Mangas sampai Pulau Rote.

Kemajemukan suku bangsa tersebut berdampak pada kemajemukan budaya setiap masyarakatnya. Perbedaan dan keanekaragaman yang ada mencakup tradisi, adat istiadat, pranata kekerabatan dan budaya material serta berbagai aspek budaya dari masing-masing suku bangsa (Hidayah, 2015, p. vii). Sementara itu, berdasarkan data Joshua Project, tercatat Indonesia memiliki 786 suku. Dari 786 suku yang ada, sejumlah 235 atau 29,9\% merupakan suku terabaikan dengan populasi sebesar 165.522.000 jiwa (Joshua, n.d.). Jumlah tersebut menunjukkan bahwa ladang misi di Indonesia masih banyak yang perlu digarap. Ada banyak pekerja dibutuhkan karena mereka layak mendengar berita keselamatan di dalam Tuhan Yesus Kristus dan dengan demikian memberikan peluang bagi orang-orang yang dipanggil oleh Allah untuk menjadi misionaris. Apabila satu suku terabaikan membutuhkan satu orang misionaris, maka paling sedikit dibutuhkan 235 orang misionaris untuk pergi dan menjangkau suku-suku tersebut.

Masyarakat yang tinggal di setiap suku bangsa di Indonesia juga memiliki kemajemukan agama. Berdasarkan data yang tercatat dalam situs Kementerian Agama, pada tahun 2016 tercatat ada enam agama yang diakui di Indonesia dengan jumlah penganut masingmasing tersebar di 33 provinsi adalah: (1) Islam, sebanyak 207.176.162 atau 87,21\%, (2) Kristen, sejumlah 16.528 .513 atau $6,96 \%$, (3) Katolik, sejumlah 6.907 .873 atau $2,91 \%$, (4) Hindu, sebanyak 4.012 .116 atau $1,69 \%$, (5) Buddha, sejumlah 1.703 .254 atau $0,72 \%$, dan (6) Konghucu, sebanyak 117.091 atau 0,05\%. Adapun orang-orang yang menganut berbagai aliran kepercayaan tercatat berjumlah 1.196.317 atau 0,50\% (Kementerian Agama, 2016).

Pada tanggal 7 November 2017, melalui keputusan Mahkamah Konstitusi (MK), pemerintah Indonesia mengakui bahwa para penganut aliran kepercayaan mempunyai kedudukan hukum yang sama dengan penganut keenam agama yang diakui oleh pemerintah dalam memperoleh hak terkait administrasi kepen- 
dudukan (Suryowati, 2017). Keputusan tersebut dapat mengakibatkan bertambahnya statistik penganut aliran kepercayaan oleh karena mereka tidak akan mendapat perlakuan yang berbeda lagi baik dari masyarakat maupun dari pemerintah. Mereka tidak akan merasa malu atau takut karena merasa ilegal. Ada kemungkinan pada tahun 2018 data statistik tersebut berubah. Akan tetapi, jumlah yang telah tercatat tersebut menunjukkan bahwa masyarakat Indonesia sangat membutuhkan Injil Kristus.

Beberapa suku di Indonesia masih mempercayai dan mempraktikkan animisme dan agama suku. Meskipun mereka mengaku menganut agama tertentu, tidak jarang praktikpraktik kepercayaan tradisional masih berlangsung. Dengan demikian terjadilah sinkretisme. Sinkretisme adalah penggantian kebenarankebenaran Injil yang merupakan inti atau yang penting dengan elemen-elemen non-Kristen (Moreau et al., 2015, p. 22). Sinkretisme dapat terjadi baik dalam bentuk sinkretisme budaya maupun pandangan dunia yang sinkretistik.

Dari pemaparan mengenai suku-suku terabaikan di Indonesia, diketahui bahwa misionaris yang akan melayani di Indonesia akan berhadapan dengan hal-hal tersebut di atas. Ia bukan hanya dituntut untuk mampu menyesuaikan diri dan menjalin relasi dengan satu komunitas dalam satu wilayah, satu budaya, dan satu bahasa baru, melainkan juga mampu berhadapan dengan praktik-praktik spiritual yang dilakukan baik secara nyata maupun diam-diam oleh masyarakat suku yang dilayaninya. Dengan demikian seleksi yang baik terhadap calon misionaris sangat penting untuk dilakukan oleh gereja-gereja maupun lembaga-lembaga misi yang ada di Indonesia. Seleksi yang baik diperlukan karena misionaris yang akan diutus harus masuk ke wilayah yang sebagian besar penduduknya belum pernah mendengar Injil. Calon misionaris perlu memiliki kualifikasi berkenaan dengan panggilan dan visinya di suku terabai, memiliki ke- trampilan dan pengetahuan akan suku yang akan dilayaninya, mempunyai kemampuan untuk beradaptasi dan berelasi dengan orangorang dari budaya yang berbeda, serta memiliki pengetahuan alkitabiah dan kemampuan untuk melakukan kontekstualisasi dalam penyampaian kabar baik.

\section{Proses dan Prosedur Seleksi}

Proses seleksi calon misionaris yang akan diutus melayani ke ladang misi akan diuraikan ke dalam empat tahapan. Pertama, tahap pendaftaran atau perekrutan. Pendaftaran berarti seseorang mendaftarkan dirinya kepada lembaga misi, baik melalui gereja atau dengan inisiatifnya sendiri. Perekrutan berarti gereja atau lembaga misi menarik orang yang dipandang memenuhi persyaratan untuk menjadi calon misionaris. Oleh karena Indonesia merupakan negara kepulauan yang majemuk dalam suku bangsa, budaya, agama, ras dan bahasa, maka orang yang disebut sebagai misionaris bukan hanya mereka yang berasal dari luar negeri, melainkan juga dari dalam negeri. Pelayan Tuhan dari Indonesia yang rela melintasi geografis dan budaya untuk melayani ke suku-suku terabaikan di wilayah Indonesia juga dapat disebut sebagai misionaris. Prosedur tahap pendaftaran/ perekrutan ini sebagai berikut: 1) calon misionaris yang telah mendaftar/direkrut mengisi formulir berisi biodata calon; 2) menyerahkan berkas-berkas yang diperlukan, yaitu: fotokopi KTP, fotokopi ijazah dan transkrip, fotokopi sertifikat pelatihan misi (bagi yang memiliki), Surat Keterangan Berkelakuan Baik dari kepolisian, pas foto; 3) menyerahkan surat referensi dari gereja lokal

Kedua tahap wawancara. Wawancara dilakukan untuk menanyakan hal-hal yang sifatnya personal, dilakukan dengan prosedur sebagai berikut: 1) wawancara dengan staf lembaga misi seputar hal komitmen sebagai seorang Kristen, kemantapan panggilan, motivasi dan visi menjadi misionaris, pe- 
ngalaman pelayanan dan/atau pelatihan; 2) wawancara dengan misionaris seputar hal kehidupan rohani, karunia rohani, suku atau daerah yang ingin dilayani, kemampuan berkomunikasi, kemampuan beradaptasi, kesediaan untuk akuntabilitas; 3) Wawancara dengan psikolog. Hal-hal yang ditanyakan meliputi tipe kepribadian, karakter Kristen, hubungan dengan orang-orang lain, dan areaarea sensitif seperti kehidupan seksual, kehidupan lajang atau pernikahan, pengalaman okultisme dan penggunaan obat-obatan terlarang.

Ketiga, penilaian atau tes. Penilaian yang dilakukan oleh ahli sesuai bidangnya, yang meliputi:1) tes pengetahuan alkitab dan doktrin; 2) tes psikologi baik IQ maupun EQ; dan 3) tes medis. Keempat, pengumuman hasil seleksi. Pengumuman hasil seleksi diberikan setelah calon menyelesaikan seluruh rangkaian kegiatan dalam proses seleksi. Dalam tahap ini ada baiknya apabila pengumuman tidak disampaikan melalui media seperti surat, surel, dan telepon. Calon dipanggil untuk datang dan pengumuman tersebut disampaikan secara tatap muka. Penjelasan yang rinci mengenai alasan diterima atau tidaknya seorang calon diperlukan dalam penyampaian keputusan.

\section{DAFTAR RUJUKAN}

Bradley, Z. (2015). The Sending Church Defined. Upstream Collective.

Coustneau, A. E. (n.d.). Predictors of missionary job success: A review of the literature and research proposal. $A P A$ PsycNet. https://psycnet.apa.org/record/ 2011-01797-008

Data, S. (n.d.). Penduduk Indonesia menurut Provinsi 1971, 1980, 1990, 1995, 2000 dan 2010. 2012. Retrieved September 19, 2018, from https://www.bps.go.id/ statictable/2009/02/20/1267/pendudukindonesia-menurut-provinsi-1971-1980-
Pihak lembaga misi perlu bersikap bijaksana ketika menyampaikan keputusan penolakan supaya calon tersebut dapat menerima dengan lapang dada. Sedangkan bagi calon yang diterima, pihak lembaga misi akan memberitahukan kelanjutan dari proses tersebut, misalnya mengikuti persiapan dan pelatihan misi yang diadakan sebelum diutus ke ladang misi yang ditentukan.

\section{KESIMPULAN}

Kebutuhan akan misionaris di Indonesia sangat besar. Meskipun hanya sedikit orang yang bersedia untuk menjadi misionaris bagi suku-suku terabaikan di Indonesia, seleksi terhadap calon misionaris merupakan hal yang penting untuk dilakukan baik oleh gereja maupun oleh lembaga misi. Tujuan diadakannya seleksi tersebut adalah untuk menemukan orang yang tepat di tempat yang tepat dan pada waktu yang tepat. Gereja dan lembaga misi harus bekerja sama dan bersungguh-sungguh dalam melakukan proses seleksi. Berbagai faktor perlu dinilai dan dipertimbangkan dari dalam diri calon. Dengan seleksi yang baik, maka diharapkan dapat mengurangi terjadinya para misionaris yang mengundurkan diri dari ladang misi sebelum waktunya.

1990-1995-2000-dan-2010.html

Data, S. (2015). Mengulik Data Suku di Indonesia. https://www.bps.go.id/news/ 2015/11/18/127/mengulik-data-suku-diindonesia.html

Databoks. (2018). 2018, Jumlah Penduduk Indonesia Mencapai 265 Juta Jiwa. https:// databoks.katadata.co.id/datapublish/ 2018/05/18/2018-jumlah-pendudukindonesia-mencapai-265-juta-jiwa

Sills, D. (2008). The Missionary Call: Find Your Place in God's Plan for the World. Moody Publishers.

Ekström, B. (1997). "The Selection Process And the Issue of Attrition" in Too Valuable to Lose, 
ed. William D. Taylor. William Carey Library.

Foyle, M. (1988). "How to Choose the Right Missionary" in Helping Missionaries Grow, eds. Kelly S. O'Donnell and Michèle Lewis O'Donnell,. William Carey Library.

Gallego, F. A., \& Woodberry, R. (2010). Christian missionaries and education in former african colonies: How competition mattered. Journal of African Economies, 19(3), 294-329.

Hakim, S. Y. (2019). Misionaris dan Keluarga. Efata, 5(1), 18-30. https://ejournal.sttiman.ac.id/index.php/studika/ article/viewFile/12/11

Hale, T. (1995). On Being A Missionary. William Carey Library.

Hay, R. (2007). Worth Keeping. William Carey Library.

Hidayah, Z. (2015). Ensiklopedi Suku Bangsa di Indonesia ed. 2. Yayasan Pustaka Obor Indonesia.

Johnston, L. N. (1997). "Should I Be a Missionary?" in Helping Missionaries Grow: Readings in Mental Health and Missions, eds. Kelly S. O'Donnell and Michèle Lewis O’Donnell. William Carey Library.

Joshua, P. (n.d.). Country: Indonesia. Retrieved September 19, 2018, from https:// joshuaproject.net/countries/ID

Kementerian Agama, J. B. H. M. (2016). Kementrian Agama Ri Dalam Angka 2016. http://www.kemenag.go.id

Liberty, R. Z. (2012). Growing Missionaries Biblically A Fresh Look at Missions in African Contex. Universe, Inc.,.

McKaughan, P. (1997). "Missionary Attrition: Defining the Problem" in Too Valuable to Lose, ed. William D. Taylor. William Carey Library.

Moreau, A. S., Corwin, G. R., \& McGee, G. B.
(2015). Introducing World Missions, Second Edition: A Biblical, Historical, and Practical Survey. Baker Academic.

Platt, D. (1997). "A Call to partnership In the Missionary Selection Process" in Too Valuable to Lose, ed. William D. Taylor. William Carey Library.

Schubert, E. (1992). "Current Issues in Screening and Selection" in Missionary Care: Counting the Cost for World Evangelization, ed. Kelly O'Donnel. William Carey Library.

Strand, M. A., Pinkston, L. M., Chen, A. I., \& Richardson, J. W. (2015). Mental Health of Cross-Cultural Healthcare Missionaries. Journal of Psychology and Theology, 43(4), 283-293. https://doi.org/ 10.1177/009164711504300406

Sudjono, A. (2013). Mentalitas Misionaris. Antusias: Jurnal Teologi dan Pelayanan, 2(4), 60-71.

Suryowati, P. E. (2017). Putusan MK Membuat Eksistensi Penghayat Kepercayaan Diakui Negara. https://nasional.kompas.com/ $\mathrm{read} / 2017 / 11 / 07 / 18573861 /$ putusanmk-membuat-eksistensi-penghayatkepercayaan-diakui-negara

Taylor, J. G. (2003). Indonesia: Peoples and Histories. Yale University Press/New Haven \& London.

Taylor, W. D. (1997). "Examining the Iceberg Called Attrition" in Too Valuable to Lose, ed. William D. Taylor. William Carey Library.

Wilson, D. J. (2015). Mind the Gaps: Engaging the Church in Missionary Care. Believers Press.

Winter, R. D. (2002). Finishing the Task: The Unreached Peoples Challenge. International Journal of Frontier Missions, 19(4), 15-25. .

Zeid, M. (2008). Metode Penelitian Kepustakaan. Yayasan Obor Indonesia. 